\title{
Morphogenesis of Silicovanadate Glasses: Investigation of Physical Properties
}

\author{
Md. Moinul lslam ${ }^{1}$, Md. Abdur Rashid ${ }^{1}$, Md. Parvez Ahamed ${ }^{l}$, Md. Emran Hossain ${ }^{2}$, M. Rafiqul Ahsan ${ }^{l}$, M. \\ Golam Mortuza ${ }^{1}$, Mirza Humaun Kabir Rubel ${ }^{3, *}$
}

${ }^{1}$ Department of Physics, University of Rajshahi, Rajshahi-6205, Bangladesh

${ }^{2}$ Physics Discipline, University of Khulna, Khulna-9208, Bangladesh

${ }^{3}$ Department of Materials Science and Engineering, University of Rajshahi, Rajshahi-6205, Bangladesh

Received: March 13, 2021, Revised: April 29, 2021, Accepted: April 29, 2021, Available Online: May 21, 2021

\begin{abstract}
In this article, we demonstrate the synthesis and various characterizations of silicovanadate glasses of $\mathrm{xSiO}_{2}(100-\mathrm{x}) \mathrm{V}_{2} \mathrm{O}_{5}$ for $\mathrm{x}=$ (10-50) mol\%, glasses which are prepared by the melt quenching method. FTIR spectra analysis confirms dominant chemical bonds among silicon, vanadium, and oxygen elements as expected. The assigned chemical bonds are $\mathrm{Si}-\mathrm{O}-\mathrm{Si}, \mathrm{O}-\mathrm{Si}-\mathrm{O}, \mathrm{V}-\mathrm{O}-\mathrm{V}, \mathrm{V}=\mathrm{O}, \mathrm{Si}-\mathrm{O}-\mathrm{V}$, $\mathrm{O}-\mathrm{H}$ from FTIR spectra. The IR spectra of all glass specimens were baseline corrected and deconvoluted to distinct peaks of chemical bonds in overlapped Gaussians with employing computer program. The chemical bond's position shifted and affected due to the addition of vanadium pentaoxide by the heat treatment process. The X-ray diffractions (XRD) patterns of glass samples exhibit partial crystalline nature for $10 \mathrm{~S} 90 \mathrm{~V}$ and $50 \mathrm{~S} 50 \mathrm{~V}$ that is influenced by high-temperature application. The differential thermal analysis (DTA) of base and heat-treated specimen determines the glass transition $\left(T_{g}\right)$, crystallization, and liquidus temperature with prominent exothermic and endothermic reactions. It is seen that the $\mathrm{pH}$ of the glass specimens abruptly changes due to the surface effect of $\mathrm{V}_{2} \mathrm{O}_{5}$ while bulk effects become robust after about 30 minutes. The measured hardness of three glass samples shows high $H_{\mathrm{V}}$-values and a slight linear increment is observed for higher $\mathrm{V}_{2} \mathrm{O}_{5}$ contents. The current-voltage (I-V) characteristic connected to the electrical conductivity of the glass specimen $(20 \mathrm{~S} 80 \mathrm{~V})$ shows a relatively higher and non-linear trend of conductivity which reveals the behavior of a semiconductor. Moreover, temperature-dependent electrical resistivity measurement of the same sample (20S80V) manifests the semiconducting nature up to $427^{\circ} \mathrm{C}$ as well.
\end{abstract}

Keywords: Si/V-based glass, FTIR, X-ray diffraction, DTA, pH, Current-Voltage characteristics, Electrical resistivity.

This work is licensed under a Creative Commons Attribution-Non Commercial 4.0 International License.

\section{Introduction}

Glass-ceramics are polycrystalline or amorphous substances possessing the properties of hardness, rigidity, brittleness which are prepared by controlled crystallization processes. Glass ceramics have widespread attentive technological applications in various fields such as electronic devices, optical devices, reflecting windows, ray absorbers, mechanical sensors, electrooptic devices, sealants, etc. [1]-[4]. Among various oxides glasses, the silicovanadate glasses have great scientific vast technological, and attractive industrial interest for their individual characteristics. To know the structural information, electrical conductivity, hardness, solubility, and optical properties of this silicovanadate glasses various characterization techniques such as X-ray diffraction, Fourier Transform IR study, Four probe method, Vickers hardness testing system, $\mathrm{pH}$ meter [5]-[8], etc., have been utilized where vanadium metal manifests various physical and chemical properties. However, some oxide glasses are generally insulating type in the aspect of conductivity but the addition of some transition metal such as VO, $\mathrm{V}_{2} \mathrm{O}_{5}, \mathrm{Fe}_{2} \mathrm{O}_{3}, \mathrm{WO}_{3}, \mathrm{ZnO}$, etc. make these glasses semiconducting.

These binary oxide glasses are studied widely for their attractive potential applications in various fields such as optical and electrical memory switching, solid state devices, and optical fibers [9]. For making useful memory and switching devices in various fields $\mathrm{V}_{2} \mathrm{O}_{5}$ containing glasses are extensively used for its transition behavior. In order to get silicovanadate glasses,
$\mathrm{V}_{2} \mathrm{O}_{5}$ is used among various transition metals because of having electrical conductivity due to the electron hopping behavior between $\mathrm{V}^{5+}$ and $\mathrm{V}^{4+}$ ions [10]-[13]. In this $\mathrm{xSiO}_{2}(100-\mathrm{x}) \mathrm{V}_{2} \mathrm{O}_{5}$ binary system glasses, $\mathrm{Si}^{4+}$ ions act as network forming ions whereas vanadium ions might act diverse role either as network formers, modifiers, and/or intermediate in the amorphous glass network [14]. The most important property of the glassy materials is the viscosity which makes the glass in liquid nature and is also closely connected with the nature and structure of the melts [15]-[16]. Besides, the addition of the network modifier component in the composition increases the density as the network modifier ions attempt to occupy the interstices within the network. Noteworthy, the hardness of glasses makes strength and density of packing of the atoms in the localized structure [17]. During the course of this investigation, the microhardness (GPa) of silicate-based glasses has been studied to investigate mechanical performance on the basis of well-established factors [18]-[22]. The electrical conductivity of a glass system usually changes due to the presence of network modifiers [14]. $\mathrm{V}_{2} \mathrm{O}_{5}$ exhibits semi-conductivity for the presence of $\mathrm{V}^{5+}$ and $\mathrm{V}^{4+}$ oxidation states that originate electron hopping between these two ions [23]-[24]. Recently, the electrical properties of several new V/Fe-based glasses have been analyzed to relate the structure and electrical conductivity $(\sigma)$ for their important applications [25]-[30]. Moreover, the chemical durability and possible improvement of the aforementioned glasses with electrical conductivity have also been analyzed [25]. Following this, the solubility of our prepared glasses in air condition has 
been measured by means of $\mathrm{pH}$ meter to explore physiochemical changes in the specimens. Therefore, in this article, we have prepared and established a relationship between local structure and physical properties such as electrical conductivity, hardness, thermal behavior, and solubility of several silicovanadate glasses by FTIR, XRD, four-probe method, DTA, $\mathrm{TCR}$, and $\mathrm{pH}$ meter for the first time.

\section{Materials and Methods}

For the synthesis of silicovanadate glasses by the conventional melt quenching method, commercially available reagents $\mathrm{SiO}_{2}$ and $\mathrm{V}_{2} \mathrm{O}_{5}$ were chosen as starting compositions. The chemicals Vanadium oxide $\left(\mathrm{V}_{2} \mathrm{O}_{5}\right)$ and Silica $\left(\mathrm{SiO}_{2}\right)$ were collected from Merck Specialties Pvt. Ltd. Worli, Mumbai400018. These chemicals were used directly without any further purification. For the preparation of $20 \mathrm{gm}$ batch of $\mathrm{xSiO}_{2}(100-$ $\mathrm{x}) \mathrm{V}_{2} \mathrm{O}_{5}$ glass system the collected raw materials were homogeneously mixed both in an agate mortar and ball-milled machine for 6-8 hours. The mixture was then poured into a porcelain crucible and melted in an electric carbolite furnace at $\sim 1500{ }^{\circ} \mathrm{C}$ for 1 hour. Dull brown transparent glass specimens were observed after sudden quenching using steel block and hammer assembly. Afterward, the base glass samples were placed in an Aluminum crucible and heated at $500{ }^{\circ} \mathrm{C} / 1 \mathrm{~h}$ to study the differences in physical properties post heat treatment.

FTIR spectra of the silicate vanadate glasses were collected on a Spectrum 100, Perkin Elmer spectrophotometer by KBr disk method within the wavenumber of 400 and $4000 \mathrm{~cm}^{-1}$ to know all possible chemical bonds. X-ray diffraction patterns of base and heat-treated glasses were examined using the monochromatic $\mathrm{CuK}_{\alpha}$ radiation by setting $2 \theta$ in the range of $5^{\circ}$ to $50^{\circ}$ at a scanning rate of $0.02^{\circ}$ with Philips "X-pert Pro XRD system". Crystal phases were detected based on standards compiled by the International Center for Diffraction Data (ICDD). The important phase transformations and crystallization temperatures were investigated by a STA- 8000 DTA model (Parkin Elmer) meter as well. Differential thermal analysis (DTA) was carried out from room temperature (RT) to $900{ }^{\circ} \mathrm{C}$ by varying the heating rate from 5 to $10{ }^{\circ} \mathrm{C} \mathrm{min}{ }^{-1}$. During the measurement, about ten milligrams of $\alpha-\mathrm{Al}_{2} \mathrm{O}_{3}$ powder and finely pulverized glass were utilized as a reference sample. To investigate physical and chemical changes the solubility of the glass specimens is measured with the aid of a $\mathrm{pH} / \mathrm{mv}$ meter (Model-PHS-25, China). In this experiment, the scale of the meter was calibrated using Potassium hydrogen phthalate of $(\mathrm{pH}$ $=4.0)$ and the Sodium tetraborate of $(\mathrm{pH}=9.18)$ to read $\mathrm{pH}$ directly. Temperature-dependent electrical conductivity $(\sigma)$ and resistivity $(\rho)$ were carried out by employing dc four-probe method for 20S80V glass specimen only. The glass specimen was cut into a rectangular shape and each longitudinal edge was connected by the probe(s) using Ag solder. The electrical current (I) was recorded through alternating voltage between 1.0 and 15 $\mathrm{V}$, on the other hand, the voltage $(\mathrm{V})$ was registered by changing electrical current between 1.0 and $2.0 \mathrm{~mA}$ along both length and width direction. Moreover, the electrical conductivity $(\sigma)$ of glass sample was evaluated on the basis of the following equation: $\sigma=$ $\mathrm{R}^{-1} \cdot \mathrm{S}^{-1} \cdot l$; where $\mathrm{R}, \mathrm{S}$, and $l$ are electrical resistivity $(\Omega)$ estimated from a slope of the straight line of V vs. I, surface area $\left(\mathrm{cm}^{2}\right)$ and electrode distance $(\mathrm{cm})$, respectively.

The microhardness of the prepared glasses was as curtained by Vickers indentation (Matsuzawa microhardness tester (MXT$\alpha 1)$ equipped with a pyramidal diamond indenter under (100 g load, $20 \mathrm{~s}$ ) by neglecting the size effects of indentation [17],[26][27]. The $H_{\mathrm{V}}$-values $(\mathrm{GPa})$ of glass samples were calculated from the expression as given, $H_{\mathrm{V}}=1854 \mathrm{~F} / \mathrm{d}^{2}$, here $\mathrm{F}=9.81 \mathrm{~N}$, and $\mathrm{d}$ is the average indentation diagonal in $\mu \mathrm{m}$, as reported elsewhere [26]. The values are recorded on averages over $8-10$ independent measurements. The indentations were examined and evaluated via the attached high-resolution microscope.

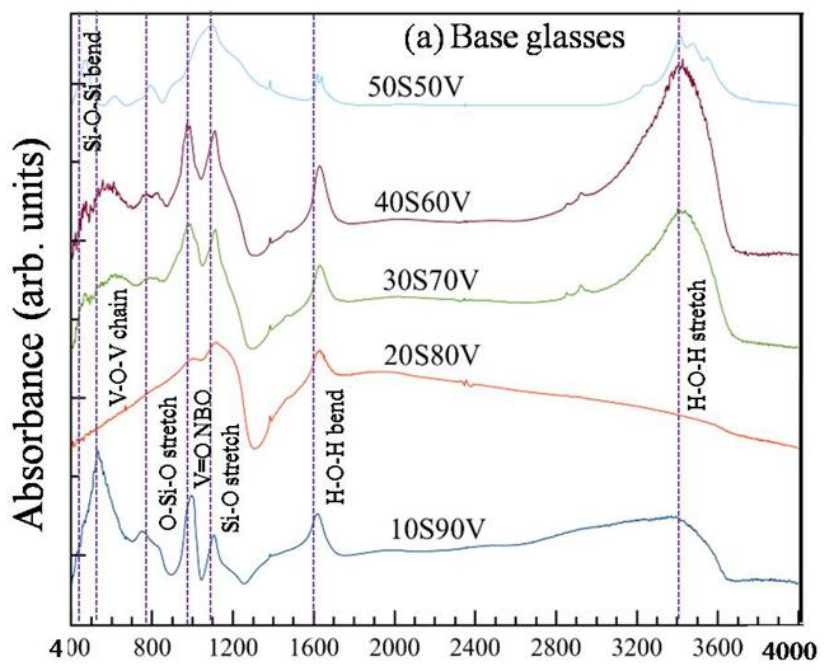

(a)

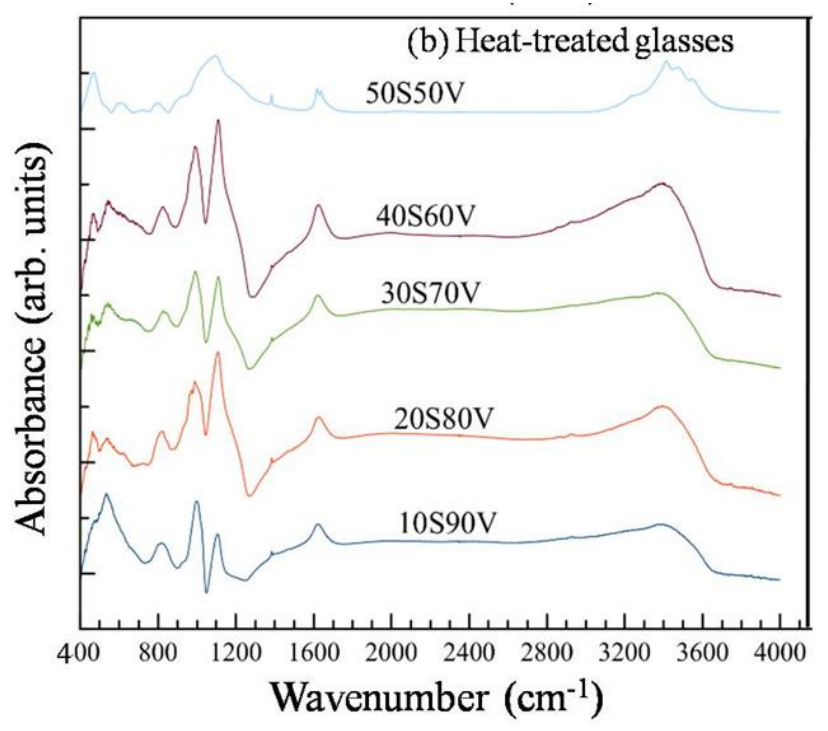

(b)

Fig. 1 Infrared spectra of (a) base glass and (b) heat-treated glass samples.

\section{Results and Discussion}

\subsection{FTIR Analysis of Silicovanadate Glasses}

Fourier Transform Infrared (FTIR) absorption spectra of glasses usually provide significant and valuable information on the arrangement of atoms, the chemical bonding between them, and the changes in atomic configurations caused by the increase or decrease of concentration of glass-forming systems. FTIR absorbance spectra of different silicate vanadate glasses are recorded from $400 \mathrm{~cm}^{-1}$ to $4000 \mathrm{~cm}^{-1}$ at room temperature. Fig. 1 (a) and 1(b) show FTIR spectra of $\mathrm{xSiO}_{2}(100-\mathrm{x}) \mathrm{V}_{2} \mathrm{O}_{5}$ of base glass and heat-treated glass samples respectively, with assigned prominent bonds and added vanadium pentaoxide contents. The 
interpretation of the IR-spectra is based on the literature data of a series of crystalline and amorphous vanadate phases [29]-[34]. The Structural groups are assigned respectively, $\mathrm{Si}-\mathrm{O}-\mathrm{Si}$ bonds for bending vibration in 458-466 $\mathrm{cm}^{-1}$ [35]-[37], V-O-V bonds for chain vibration in 512-552 $\mathrm{cm}^{-1}$ [38]-[41].

$\mathrm{V}-\mathrm{O}-\mathrm{V}$ bonds for bending vibration in $593-624 \mathrm{~cm}^{-1}$ [42], O$\mathrm{Si}-\mathrm{O}$ bonds for symmetric stretching vibration in $798 \mathrm{~cm}^{-1}$ [43], $\mathrm{V}-\mathrm{O}-\mathrm{V}$ bonds for asymmetric stretching vibration in $822-826$ $\mathrm{cm}^{-1}$ [44], Si-O-V bonds for vibration in $911 \mathrm{~cm}^{-1}$ [45], $\mathrm{V}=\mathrm{O}$ bonds for non-bridging in 980-998 $\mathrm{cm}^{-1}$ [46], Si-O-Si bonds for asymmetric stretching vibration in $1073 \mathrm{~cm}^{-1}$ [47], Si-O bonds for asymmetric stretching vibration in $1104-1227 \mathrm{~cm}^{-1}$ [48]-[50]. Whereas, $\mathrm{O}-\mathrm{H}$ bonds for vibration in $1385-1523 \mathrm{~cm}^{-1}$ [51], H-O$\mathrm{H}$ bonds for bending vibration in 1601-2028 $\mathrm{cm}^{-1}$ [52]-[56], $\mathrm{H}-$ $\mathrm{O}-\mathrm{H}$ bonds for symmetric stretching vibration in $3403-3447 \mathrm{~cm}^{-}$ ${ }^{1}$ [57]-[58] for hygroscopic nature. However, we did not observe any significant change in the FTIR spectra of our synthesized glass samples even after heat treatment. The structural groups and main bonds of heat-treated samples remain in almost harmonious peak positions like base glasses, except a slight change in their intensity. This means that the local structure of the synthesized glass specimens did not alter after heat treatment up to $500{ }^{\circ} \mathrm{C}$. Table 1 displays several physical properties including melting temperature during synthesis of all glasses. However, the melting temperature of $50 \mathrm{~S} 50 \mathrm{~V}$ sample was undetermined or known due to a large amount of silica (melting temperature $\sim 1700{ }^{\circ} \mathrm{C}$ ) present.

Table 1 Melting temperature and optical quality of the glasses of various compositions.

\begin{tabular}{|c|c|c|c|c|c|}
\hline \multirow[t]{2}{*}{ Samples } & \multicolumn{2}{|c|}{$\begin{array}{c}\text { Nominal } \\
\text { composition } \\
(\mathrm{mol} \%)\end{array}$} & \multirow[t]{2}{*}{$\begin{array}{c}\text { Melting } \\
\text { Temperature } \\
\left({ }^{\circ} \mathrm{C}\right)\end{array}$} & \multirow[t]{2}{*}{$\begin{array}{l}\text { Optical } \\
\text { quality }\end{array}$} & \multirow[t]{2}{*}{$\begin{array}{c}\text { X-ray } \\
\text { diffraction }\end{array}$} \\
\hline & $\mathbf{S i}_{2} \mathbf{O}$ & $\mathrm{V}_{2} \mathrm{O}_{5}$ & & & \\
\hline $10 \mathrm{~S} 90 \mathrm{~V}$ & 10 & 90 & 1200 & Transparent & $\begin{array}{c}\text { Partially } \\
\text { Crystallized }\end{array}$ \\
\hline $20 \mathrm{~S} 80 \mathrm{~V}$ & 20 & 80 & 1250 & Transparent & Amorphous \\
\hline $30 \mathrm{~S} 70 \mathrm{~V}$ & 30 & 70 & 1300 & Transparent & Amorphous \\
\hline $40 \mathrm{~S} 60 \mathrm{~V}$ & 40 & 60 & 1300 & Transparent & Amorphous \\
\hline $50 \mathrm{~S} 50 \mathrm{~V}$ & 50 & 50 & Unknown & Opaque & Amorphous \\
\hline
\end{tabular}

Table 2 Deconvoluted band positions of $\mathrm{xSiO}_{2}(100-\mathrm{x}) \mathrm{V}_{2} \mathrm{O}_{5}$ base and (heat-treated) glasses.

\begin{tabular}{|c|c|c|c|c|c|}
\hline \multirow{2}{*}{$\begin{array}{l}\text { Chemical } \\
\text { Bonds }\end{array}$} & \multicolumn{5}{|c|}{ Band position $\left(\mathrm{cm}^{-1}\right)$} \\
\hline & $10 \mathrm{~S} 90 \mathrm{~V}$ & $20 \mathrm{~S} 80 \mathrm{~V}$ & $30 \mathrm{~S} 70 \mathrm{~V}$ & $40 \mathrm{~S} 60 \mathrm{~V}$ & $50 \mathrm{~S} 50 \mathrm{~V}$ \\
\hline Si-O-Si (Bending) & $\begin{array}{c}466 \\
(480) \\
\end{array}$ & $\begin{array}{c}- \\
(463) \\
\end{array}$ & $\begin{array}{c}458 \\
(458) \\
\end{array}$ & $\begin{array}{c}464 \\
(462) \\
\end{array}$ & $\begin{array}{c}466 \\
(467) \\
\end{array}$ \\
\hline V-O-V (Chain) & $\begin{array}{c}528 \\
(543)\end{array}$ & $\begin{array}{c}- \\
(532)\end{array}$ & $\begin{array}{c}512 \\
(536)\end{array}$ & $\begin{array}{c}552 \\
(539)\end{array}$ & $\begin{array}{c}- \\
(-)\end{array}$ \\
\hline V-O-V (Bending vibration) & $\begin{array}{c}593 \\
(601) \\
\end{array}$ & $\begin{array}{c}- \\
(591) \\
\end{array}$ & $\begin{array}{c}602 \\
(632) \\
\end{array}$ & $\begin{array}{c}624 \\
(602) \\
\end{array}$ & $\begin{array}{c}616 \\
(610) \\
\end{array}$ \\
\hline $\begin{array}{c}\text { V-O (stretching } \\
\text { Vibration) }\end{array}$ & $\begin{array}{c}763 \\
(-) \\
\end{array}$ & $\begin{array}{c}736 \\
(-) \\
\end{array}$ & $\begin{array}{l}- \\
(-) \\
\end{array}$ & $\begin{array}{c}784 \\
(-) \\
\end{array}$ & $\begin{array}{c}749 \\
(728) \\
\end{array}$ \\
\hline $\begin{array}{c}\text { O-Si-O (symmetric } \\
\text { Stretching Vibration) }\end{array}$ & $(-)$ & $(-)$ & $\begin{array}{l}- \\
(-) \\
\end{array}$ & $(-)$ & $\begin{array}{c}798 \\
(799) \\
\end{array}$ \\
\hline $\begin{array}{c}\text { V-O-V (Asymmetric } \\
\text { Vibration) }\end{array}$ & $\begin{array}{c}826 \\
(820) \\
\end{array}$ & $\begin{array}{c}- \\
(815)\end{array}$ & $\begin{array}{c}822 \\
(830) \\
\end{array}$ & $\begin{array}{c}- \\
(824)\end{array}$ & $\begin{array}{l}- \\
(-)\end{array}$ \\
\hline Si-O-V (Vibration) & $\begin{array}{l}- \\
-\end{array}$ & $\begin{array}{l}- \\
-\end{array}$ & - & $\begin{array}{l}- \\
-\end{array}$ & $\begin{array}{c}911 \\
(921) \\
\end{array}$ \\
\hline $\mathrm{V}=\mathrm{O}$ (Non bridging) & $\begin{array}{c}991 \\
(987,1011)\end{array}$ & $\begin{array}{c}998 \\
(972,1007)\end{array}$ & $\begin{array}{c}991 \\
(953,997)\end{array}$ & $\begin{array}{c}980 \\
(948,992)\end{array}$ & $\begin{array}{c}- \\
(1002)\end{array}$ \\
\hline $\begin{array}{l}\text { Si-O-Si (Asymmetric } \\
\text { Stretching Vibration) }\end{array}$ & $\begin{array}{l}- \\
(-)\end{array}$ & $\begin{array}{l}- \\
(-)\end{array}$ & $\overline{(-}$ & $\begin{array}{l}- \\
(-)\end{array}$ & $\begin{array}{c}1073 \\
(1088)\end{array}$ \\
\hline $\begin{array}{c}\text { Si-O (Asymmetric } \\
\text { Stretching Vibration) }\end{array}$ & $\begin{array}{c}1105,1168 \\
(1103,1157)\end{array}$ & $\begin{array}{c}1137,1212 \\
(1100,1127, \\
1196)\end{array}$ & $\begin{array}{c}1112,1174 \\
(1107,1172)\end{array}$ & $\begin{array}{c}1104,1192 \\
(1105,1182)\end{array}$ & $\begin{array}{c}1227 \\
(1212,1261)\end{array}$ \\
\hline $\mathrm{O}-\mathrm{H}$ (vibration) & $\begin{array}{c}1390,1523 \\
(1400,1572)\end{array}$ & $\begin{array}{c}1470 \\
(1380,1503)\end{array}$ & $\begin{array}{c}1441 \\
(1405,1535)\end{array}$ & $\begin{array}{c}1385,1512 \\
(1415,1519)\end{array}$ & $(-)$ \\
\hline $\mathrm{H}-\mathrm{O}-\mathrm{H}$ (Bending vibration) & $\begin{array}{c}1619 \\
(1630)\end{array}$ & $\begin{array}{c}1616,1752 \\
2028 \\
(1629)\end{array}$ & $\begin{array}{l}1601,1633 \\
(1628)\end{array}$ & $\begin{array}{c}1632 \\
(1627)\end{array}$ & $\begin{array}{c}1635 \\
(1618,1637)\end{array}$ \\
\hline
\end{tabular}

In order to obtain the quantitative information, the spectra of the base and heat-treated glasses are deconvoluted to several Gaussians according to the presence of peaks and shoulders in the spectral shape. The high-frequency band peaks have a relatively higher intensity than low-frequency band peaks and consist of broad Gaussian. The shape of the absorption spectrum changes with increasing $\mathrm{V}_{2} \mathrm{O}_{5}$ content up to $90 \mathrm{~mol} \%$.
The structural bonds of base samples slightly shift in contrast to heat-treated samples. The FTIR spectra are divided into two regions, one in the lower wavenumber from $400 \mathrm{~cm}^{-1}$ to 1700 $\mathrm{cm}^{-1}$ and the other in the higher frequency range $1700 \mathrm{~cm}^{-1}$ $4000 \mathrm{~cm}^{-1}$. As it is difficult to identify the exact position of the absorption band thus deconvolution of these bands was carried out to obtain the exact position of the absorption band [28]. The 
deconvolution of $10 \mathrm{~S} 90 \mathrm{~V}, 20 \mathrm{~S} 80 \mathrm{~V}, 30 \mathrm{~S} 70 \mathrm{~V}, 40 \mathrm{~S} 60 \mathrm{~V}$, and $15 \mathrm{~S} 50 \mathrm{~V}$ base and heat-treated glasses with baseline correction are shown in Fig. A1.

The spectra exhibited different absorption bands due to various structural units of $\mathrm{SiO}_{2}$ and $\mathrm{V}_{2} \mathrm{O}_{5}$. Further, the deconvolution method also can calculate the relative area of each component band and band positions of base and heat-treated glasses (Fig. A2). The concentration of the structural group is proportional to the relative area of its component bands. The summary of the data on various absorption bands observed in the deconvolution IR spectra of $\mathrm{xSiO}_{2}(100-\mathrm{x}) \mathrm{V}_{2} \mathrm{O}_{5}$ of base and heat-treated glasses are presented in the values within (heat-treated) are indicated for heat-treated glasses.

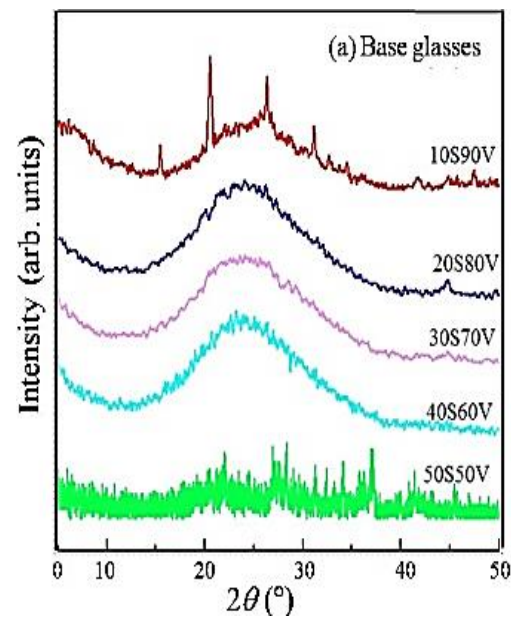

(a)

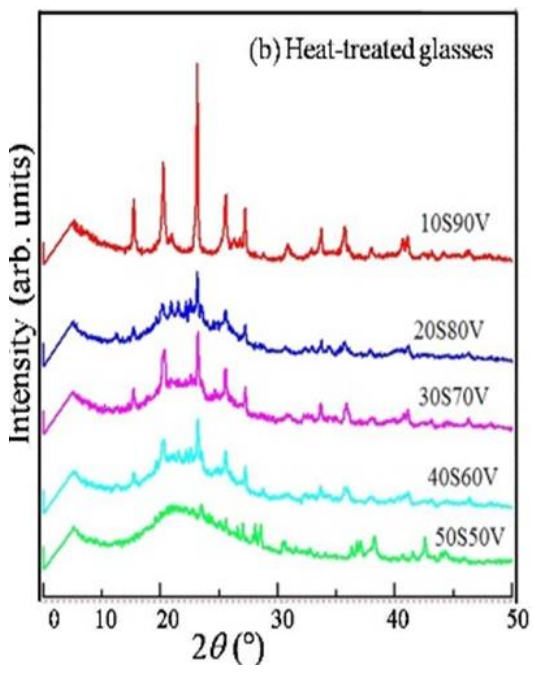

(b)

Fig. 2 The X-ray diffraction patterns of (a) base and (b) heattreated glass samples.

\subsection{XRD analysis of silicovanadate glasses}

To know the crystalline nature of the prepared base and heattreated glass samples X-ray diffraction patterns were collected and analyzed, which are shown in Fig. 2. The XRD patterns of base glass samples are shown in Fig. 2(a). All the base glass samples display weak diffuse diffraction patterns with amorphous halos except $10 \mathrm{~S} 90 \mathrm{~V}$ composition. The sample $10 \mathrm{~S} 90 \mathrm{~V}$ is partially crystallized because some peaks are observed at about $15^{\circ}, 20^{\circ}, 28^{\circ}, 32^{\circ}$ due to the formation of several phases of silicovanadate compounds. However, few weak diffuse halos are observed in the 20S80V, 30S70V, $40 \mathrm{~S} 60 \mathrm{~V}$, and $50 \mathrm{~S} 50 \mathrm{~V}$ base glasses that imply the homogeneous nature of prepared glasses. Moreover, the XRD patterns of heattreated glass samples are cumulated and shown in Fig. 2(b).

X-ray diffraction study of heat-treated glass samples shows the formation of possible primary crystalline phases of $\mathrm{SiV}_{2} \mathrm{O}_{7}$, $\mathrm{Si}_{2} \mathrm{~V}_{2} \mathrm{O}_{6}$, and $\mathrm{Si}_{2} \mathrm{~V}_{2} \mathrm{O}_{9}$ indicating the multiple combinations of elements [45]. The exact peak positions corresponding to phases of heat-treated glasses were not determined for the limited feature of the XRD machine. From X-ray diffraction patterns it is seen, the crystalline peak increases with increasing $\mathrm{V}_{2} \mathrm{O}_{5}$ contents in the case of heat-treated glass samples. Therefore, phase formation in our synthesized base glasses depends both on heat treatment and composition ratios of raw materials used.

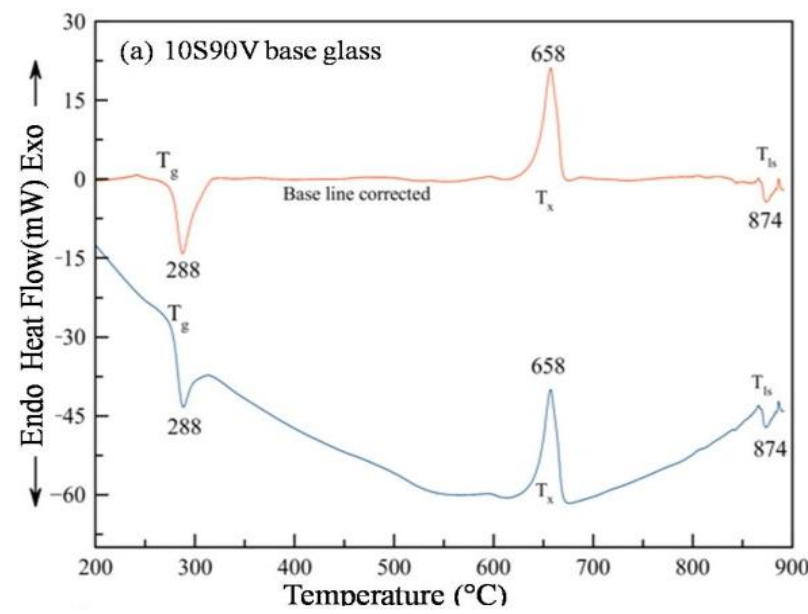

(a)

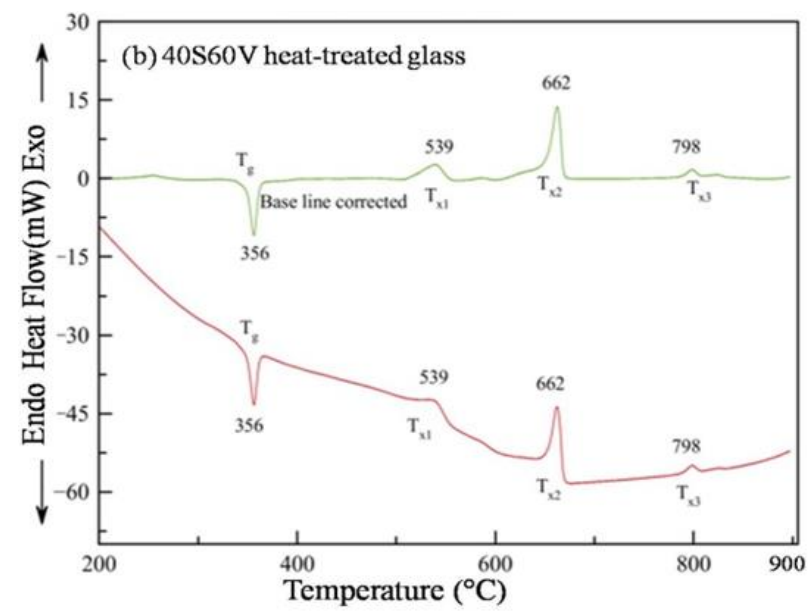

(b)

Fig. 3 DTA curves of (a) 10S90V base glass specimen and (b) 40S60V heat-treated sample.

\subsection{DTA Analysis of Silicovanadate Glasses}

Fig. 3 reveals the Differential Thermal Analysis (DTA) curves of $10 \mathrm{~S} 90 \mathrm{~V}$ base and $40 \mathrm{~S} 60 \mathrm{~V}$ heat-treated glass. The DTA traces for two glass samples are recorded in the temperature range of 30 to $900{ }^{\circ} \mathrm{C}$, but the curves are presented from 200 to $900^{\circ} \mathrm{C}$. For $10 \mathrm{~S} 90 \mathrm{~V}$ base glass, the glass transition temperature, $\mathrm{T}_{\mathrm{g}}\left(288^{\circ} \mathrm{C}\right)$, crystallization temperature, $\mathrm{T}_{\mathrm{x}}\left(658^{\circ} \mathrm{C}\right)$, and liquidus temperature $\mathrm{T}_{\mathrm{ls}}\left(874{ }^{\circ} \mathrm{C}\right)$ are recorded. The endothermic 
characteristics of the specimen are used to determine the $T_{g}$ and $\mathrm{T}_{\mathrm{ls}}$ while exothermic characteristics give $\mathrm{T}_{\mathrm{x}}$. For this composition $10 \mathrm{~S} 90 \mathrm{~V}$, the curve represents a broad exothermic peak at $658^{\circ} \mathrm{C}$ indicates $\mathrm{T}_{\mathrm{x}}$, and the endothermic peak at $874{ }^{\circ} \mathrm{C}$ is a measure of the liquidus temperature $\left(\mathrm{T}_{\mathrm{ls}}\right)$. Whereas, the base glass $40 \mathrm{~S} 60 \mathrm{~V}$ was heat-treated at $500{ }^{\circ} \mathrm{C}$ to collect DTA data as well. In this heat-treated glass sample, the glass transition temperature is raised to $356^{\circ} \mathrm{C}$ (for endothermic reaction) with three exothermic peaks that can be visually resolved in one large and two small peaks due to the crystallization. In the sample the first peak at $539^{\circ} \mathrm{C}$, the second peak at $662{ }^{\circ} \mathrm{C}$ and the third peak at $798{ }^{\circ} \mathrm{C}$ originate due to the crystallization of various phases.

Moreover, several exothermic peaks were observed owing to the formation of various possible silicovanadate compounds such $\mathrm{SiV}_{2} \mathrm{O}_{7}, \mathrm{Si}_{2} \mathrm{~V}_{2} \mathrm{O}_{6}$, and $\mathrm{Si}_{2} \mathrm{~V}_{2} \mathrm{O}_{9}$ at $539{ }^{\circ} \mathrm{C}, 662{ }^{\circ} \mathrm{C}$, and 798 ${ }^{\circ} \mathrm{C}$ respectively, as expected from $\mathrm{X}$-ray diffraction data. However, the liquidus temperature $\left(\mathrm{T}_{\mathrm{sl}}\right)$ could not be determined because of the poor endothermic response of the specimen. All DTA traces exhibit typical glass transitions with the inflection point between 250 to $380{ }^{\circ} \mathrm{C}$.

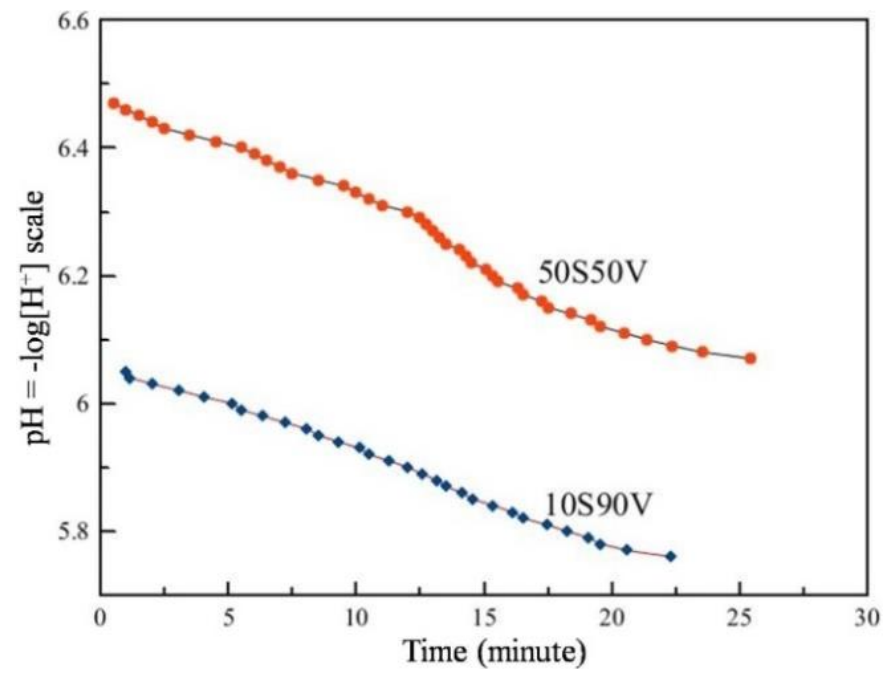

Fig. 4 Variation of $\mathrm{pH}$ of glass powder solution with time

\section{4 pH Analysis of Silicovanadate Glasses}

The $\mathrm{pH}$ measurement of glass samples is related to chemical durability which is defined as the stability of specimens under chemical attack. Lack of chemical durability that changes $\mathrm{pH}$ is mainly occurred owing to the dissolution of constituent elements in the chemical environment. It is known that higher chemical durability lowers the leaching rate of elements. A high leaching rate (lower chemical durability) is observed for high content of vanadate in contrast to more silica content glasses. The $\mathrm{pH}$ of the glass powder solution of $10 \mathrm{~S} 90 \mathrm{~V}$ and $50 \mathrm{~S} 50 \mathrm{Vcompositions} \mathrm{in}$ distilled $\mathrm{H}_{2} \mathrm{O}$ are measured for 30 minutes, shown in Fig. 4. The recorded $\mathrm{pH}$ of the distilled water before the experimentation was 7.02. Initially, the solution of $50 \mathrm{~S} 50 \mathrm{~V}$ glass powder shows the value of $\mathrm{pH}$ near 6.50 as seen from the curve. It is confirmed that the solution of this glass sample is acidic because the value of $\mathrm{pH}$ is less than 7 as there is no alkali or alkaline elements in our synthesized products. After stirring the solution by the magnetic stirrer, the value of $\mathrm{pH}$ gradually decreases owing to the leaching of silica and vanadate compositions in exponential form but after approximately 30 minutes the value of $\mathrm{pH}$ hardly changed. On the other hand, the solution of $10 \mathrm{~S} 90 \mathrm{~V}$ powder sample exhibits $\mathrm{pH} \sim 6.10$ at the beginning which shows a more acidic nature than $50 \mathrm{~S} 50 \mathrm{~V}$ glass. This means that the glass composition 10S90V exhibits lower chemical durability than that of $50 \mathrm{~S} 90 \mathrm{~V}$ composition. Therefore, due to the formation of acid in distilled water the $\mathrm{pH}$ of the glass solution decreases as the hydrogen ion concentration increases. However, initially, the abrupt change of $\mathrm{pH}$ of the specimen is observed for the surface effect of $\mathrm{V}_{2} \mathrm{O}_{5}$ but strong bulk consequence becomes prominent with time. If we carry out $\mathrm{pH}$ measurement for all compositions from $10 \mathrm{~S} 90 \mathrm{~V}$ to $50 \mathrm{~S} 50 \mathrm{~V}$ it is expected that chemical inertness (less leaching rate) will increase sequentially.

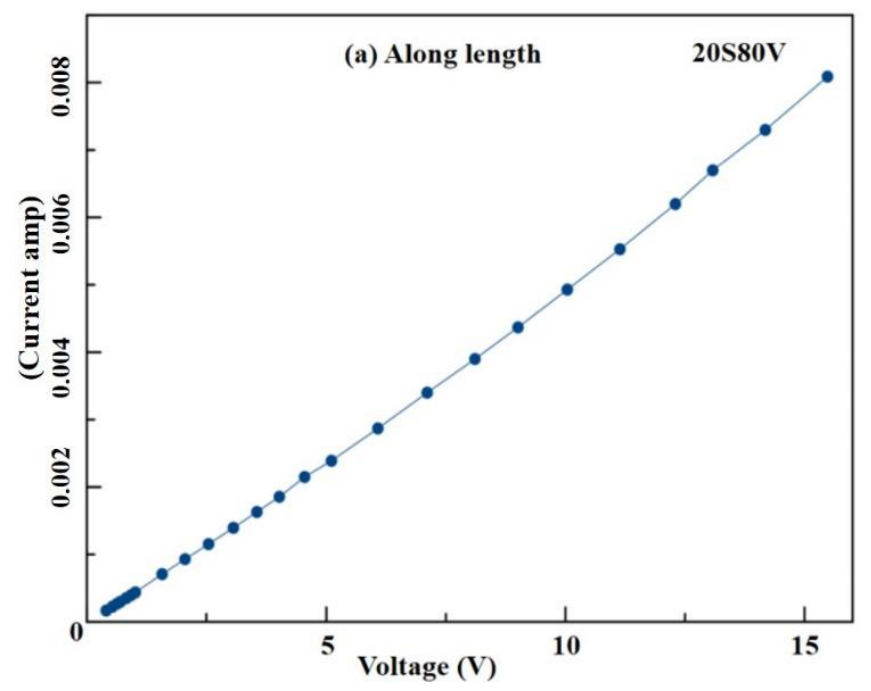

(a)

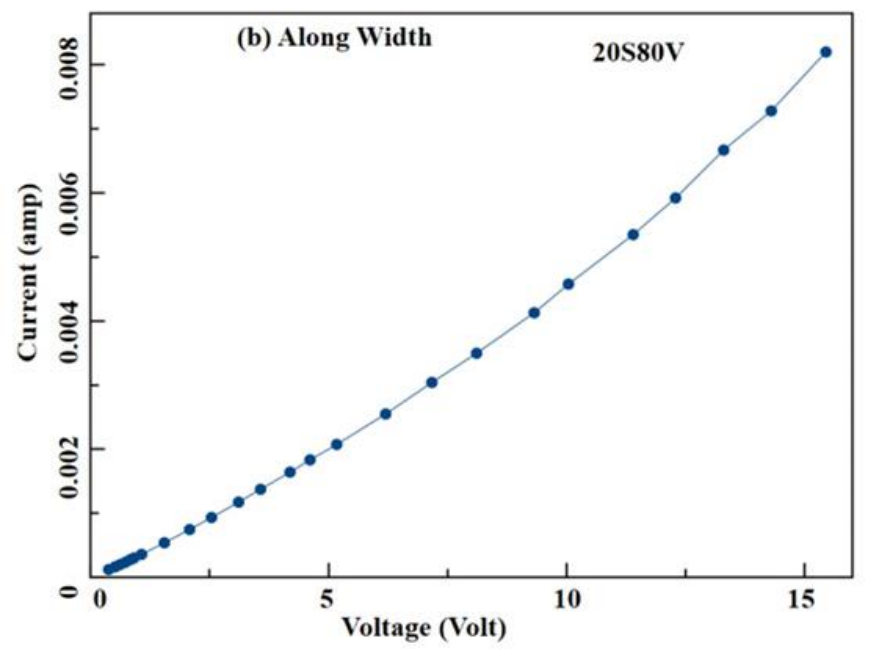

(b)

Fig. 5 I V Characteristic curve of the 20S80V base glass specimen along (a) length (b) width.

\subsection{Vickers Hardness Analysis of Silicovanadate Glasses}

Vicker hardness $(\mathrm{Hv})$ data for $10 \mathrm{~S} 90 \mathrm{~V}, 30 \mathrm{~S} 70 \mathrm{~V}$, and 40S60V base glass samples are listed in Table 3. The microhardness value of glass samples are almost comparable but vary slightly with the variation of compositions. The maximum hardness $(\sim 5.42 \mathrm{GPa})$ is observed for the glass sample $10 \mathrm{~S} 90 \mathrm{~V}$ is slightly higher than two other samples (30S90V and 40S60V). However, the microhardness of glass-ceramics is mainly governed by the various cation-oxygen bond-strengths, and the glass network connectivity, and the cross-linking degree of its various segments [20]-[21],[57],[58]. The V-O-V and $\mathrm{V}=\mathrm{O}$ bonds are weaker compared to $\mathrm{Si}-\mathrm{O}-\mathrm{Si}$ and $\mathrm{O}-\mathrm{Si}-\mathrm{O}$ that prevented the sequential intra-network links in the glassy 
structure [46]-[48]. But the bonds of V and its local structure usually join distinct network segments, which might solidify and stiff the structure for the enhancement of $H_{\mathrm{V}}$ [59].

Table 3 Vickers hardness for 10S90V, 30S70V, and 40S60V base glass samples.

\begin{tabular}{|c|c|c|c|}
\hline \multirow{2}{*}{ Samples } & \multicolumn{2}{|c|}{ Diagonal distance $(\mu \mathrm{m})$} & \multirow{2}{*}{$\mathrm{H}_{\mathrm{V}}(\mathrm{GPa})$} \\
\cline { 2 - 3 } & $\mathrm{d}_{1}$ & $\mathrm{~d}_{2}$ & \\
\hline 10S90V & $59.25(3)$ & $56.63(6)$ & $5.42(4)$ \\
\hline 30S70V & $59.63(6)$ & $59.69(7)$ & $5.11(1)$ \\
\hline 40S60V & $62.82(8)$ & $57.69(7)$ & 5.00 \\
\hline
\end{tabular}

\subsection{Electrical Conductivity $(\sigma)$ of Silicovanadate Glasses}

Current (Amp) versus voltage (V) characteristic curves for 20S80V specimen along the length and the width of the specimen are presented in Fig. 5(a) and 5(b) respectively. The $I \sim V$ characteristic curves related to electrical conductivity $(\sigma)$ increased gradually but not linearly with applied voltage. The deviated patterns of glass specimen from straight-line follow the relation, $\mathrm{I}=\mathrm{KV}^{\mathrm{n}}$ where $\mathrm{n}$ is greater than one, which is a behavior of semiconductor. Moreover, the observed value of $\sigma$ in this glass material is in the range of semi-conductivity. Moreover, Fig. 6 reveals the measured conductivity in Siemens per meter $\left(\mathrm{S} \mathrm{m}^{-1}\right)$ reaches its highest value at about $440{ }^{\circ} \mathrm{C}$. At this temperature all the impurity atoms are ionized and the number of electrons becomes maximum to get the utmost conductivity. On the other hand, the conductivity shows a sharp decreasing trend from 442 to $582{ }^{\circ} \mathrm{C}$ due to the decrease in drift mobility of electrons with the rise of temperature in this range.

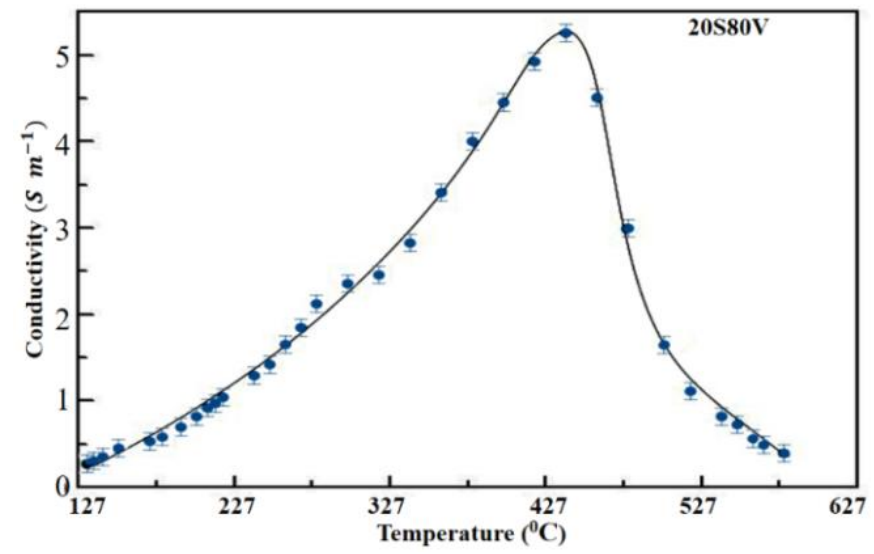

Fig. 6 Variation of conductivity with a temperature of $20 \mathrm{~S} 80 \mathrm{~V}$ base glass.

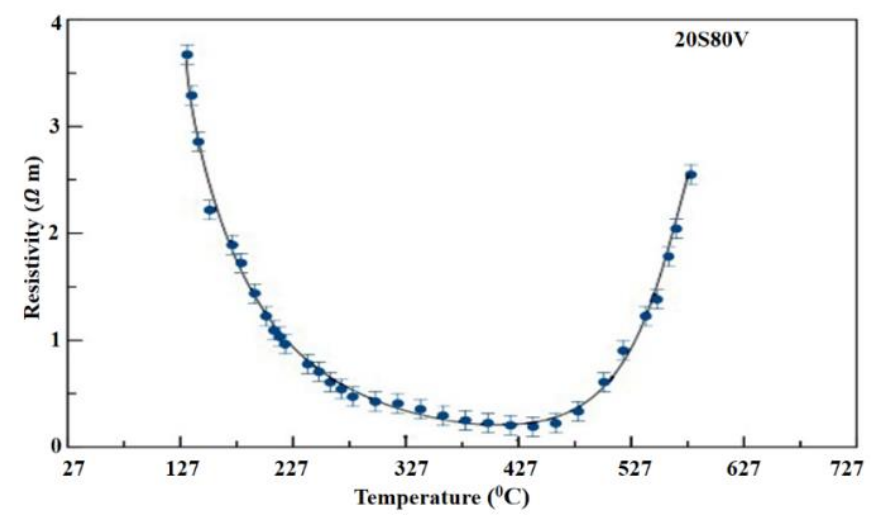

Fig. 7 Variation of resistivity with temperatures.
The measured resistivity of the specimen 20S80V decreases with increasing temperatures up to $427{ }^{\circ} \mathrm{C}$ is a behavior of semiconductor but metallic behavior is observed above this temperature (Fig. 7). This scenario is due to the increasing concentration of conduction electrons at elevated temperatures.

\section{Conclusion}

In this study, we have synthesized several silicovanadate glass samples with the variation of compositions by familiar melt quenching method. It was observed that the melting temperature of the glass samples depended on the amount of $\mathrm{V}_{2} \mathrm{O}_{5}$ present. The infrared spectra of $\mathrm{xSiO}_{2}(100-\mathrm{x}) \mathrm{V}_{2} \mathrm{O}_{5}$ glass system was interpreted in term of various chemical bonds. The FTIR chemical band positions in the glasses have a general tendency to shift towards the high-frequency region with the increase of $\mathrm{V}_{2} \mathrm{O}_{5}$ concentration. The FTIR spectra indicate that the glass samples contain various local structural units such as $\mathrm{Si}-\mathrm{O}-\mathrm{Si}, \mathrm{V}-$ $\mathrm{O}-\mathrm{V}, \mathrm{V}-\mathrm{O}, \mathrm{O}-\mathrm{Si}-\mathrm{O}, \mathrm{Si}-\mathrm{O}-\mathrm{V}$, and $\mathrm{V}=\mathrm{O}$. The effect of $\mathrm{V}_{2} \mathrm{O}_{5}$ is obvious for certain bonding mechanisms where $\mathrm{V}^{5+}$ might play a significant role. The formation of $\mathrm{O}-\mathrm{H}$ bonds expresses the hygroscopic nature of the glass which provides additional information about the structural units. The X-ray diffraction patterns of the $50 \mathrm{~S} 50 \mathrm{~V}, 40 \mathrm{~S} 60 \mathrm{~V}, 30 \mathrm{~S} 70 \mathrm{~V}, 20 \mathrm{~S} 80 \mathrm{~V}$, and $10 \mathrm{~S} 90 \mathrm{~V}$ base samples show an almost amorphous nature with several haloes. After heat treatment, the glasses have been crystallized with the formation of different silicovandate compounds. The characterization of samples by the DTA technique measured the $T_{g}, T_{x}$, and $T_{l s}$ temperatures for glass specimens and possible randomly distributed grain of different crystalline phases. The solubility measurements of glass materials manifest the acidic nature and the $\mathrm{pH}$ of the sample solution decreases with the increase of $\mathrm{V}_{2} \mathrm{O}_{5}$ in the glass composition. The measured hardness of glass samples exhibits high $\mathrm{H}_{\mathrm{V}^{-}}$values due to the presence of significant V-bonds in the glass structure. The higher and nonlinear conductivity patterns (I-V curve) of 20S80V glass can be considered for the semi-conductivity of the specimen which has also been supported by temperature-dependent electrical resistivity measurement data.

\section{Acknowledgments}

The authors highly debt to Center Science laboratory, Department of Materials Science and Engineering, University of Rajshahi, Bangladesh for FTIR data and Vickers hardness test. The authors also acknowledge the support from the Department of Glass and Ceramics, Rajshahi University of Engineering and Technology, Bangladesh for XRD measurement.

\section{References}

[1] Morey, G.W., 1954. Properties of glass, Monograph series (American Chemical Society), New York, Reinhold.

[2] Greer, A.L., 1997. Metallic glasses. Current Opinion in Solid State and Materials Science, 2(4), pp.412-416.

[3] Ahsan, M.R., Uddin, M.A. and Mortuza, M.G., 2005. Infrared study of the effect of $\mathrm{P}_{2} \mathrm{O}_{5}$ in the structure of lead silicate glasses.

[4] Seafriends.org.nz., 1994, Retrieved 2012, Mining the sea sand.

Website:

http://www.seafriends.org.nz/oceano/seasand.htm

[5] Sharma, B.K., 1991. Industrial chemistry. Krishna Prakashan Media. 
[6] ElBatal, F.H., Marzouk, S.Y., Nada, N. and Desouky, S.M., 2007. Gamma-ray interaction with copper-doped bismuth-borate glasses. Physica B: Condensed Matter, 391(1), pp.88-97.

[7] Pönitzsch, A., Nofz, M., Wondraczek, L. and Deubener, J., 2016. Bulk elastic properties, hardness and fatigue of calcium aluminosilicate glasses in the intermediate-silica range. Journal of Non-Crystalline Solids, 434, pp.1-12.

[8] Sindhu, S., Sanghi, S., Agarwal, A., Kishore, N. and Seth, V.P., 2007. Effect of $\mathrm{V}_{2} \mathrm{O}_{5}$ on structure and electrical properties of zinc borate glasses. Journal of Alloys and Compounds, 428(1-2), pp.206-213.

[9] Singh, G.P., Kaur, P., Kaur, S. and Singh, D.P., 2011. Role of $\mathrm{V}_{2} \mathrm{O}_{5}$ in structural properties of $\mathrm{V}_{2} \mathrm{O}_{5}-\mathrm{MnO}_{2}-\mathrm{PbO}$ $\mathrm{B}_{2} \mathrm{O}_{3}$ glasses. Materials Physics and Mechanics, 12, pp.58-63.

[10] Seshasayee, M. and Muruganandam, K., 1998. Molecular dynamics study of $\mathrm{V}_{2} \mathrm{O}_{5}$ glass. Solid State Communications, 105(4), pp.243-246.

[11] Mott, N.F., 1968. Conduction in glasses containing transition metal ions. Journal of Non-Crystalline Solids, 1(1), pp.1-17.

[12] John, V., 1992. Introduction to engineering materials. $3^{\text {rd }}$ Edition, Macmillan Education Ltd.

[13] Dekker, A. J., 1995. Solid-state physics, Macmillan India Limited, New Delhi, 110064.

[14] Cicconi, M.R., Lu, Z., Uesbeck, T., van Wüllen, L., Brauer, D.S. and De Ligny, D., 2020. Influence of Vanadium on optical and mechanical properties of aluminosilicate glasses. Frontiers in Materials, 7, p.161.

[15] Lewis, C.E., 1959. The biological effects of vanadium: II. The signs and symptoms of occupational vanadium exposure. Journal of Occupational and Environmental Medicine, 1(10), p.572.

[16] Kumar, V., Pandey, O.P. and Singh, K., 2010. Structural and optical properties of barium borosilicate glasses. Physica B: Condensed Matter, 405(1), pp.204-207.

[17] Limbach, R., Rodrigues, B.P. and Wondraczek, L., 2014. Strain-rate sensitivity of glasses. Journal of Noncrystalline Solids, 404, pp.124-134.

[18] Stevensson, B. and Edén, M., 2013. Structural rationalization of the microhardness trends of rare-earth aluminosilicate glasses: interplay between the RE3+ field-strength and the aluminum coordinations. Journal of Non-crystalline Solids, 378, pp.163-167.

[19] Becher, P.F., Waters, S.B., Westmoreland, C.G. and Riester, L., 2002. Compositional effects on the properties of Si-Al-RE-based oxynitride glasses $(\mathrm{RE}=\mathrm{La}, \mathrm{Nd}, \mathrm{Gd}$, $\mathrm{Y}$, or Lu). Journal of the American Ceramic Society, 85(4), pp.897-902.

[20] Rouxel, T., 2007. Elastic properties and short-to mediumrange order in glasses. Journal of the American Ceramic Society, 90(10), pp.3019-3039.

[21] Smedskjaer, M.M., Jensen, M. and Yue, Y., 2010. Effect of thermal history and chemical composition on hardness of silicate glasses. Journal of Non-crystalline Solids, 356(18-19), pp.893-897.

[22] Zheng, Q., Potuzak, M., Mauro, J.C., Smedskjaer, M.M., Youngman, R.E. and Yue, Y., 2012. Compositionstructure-property relationships in boroaluminosilicate glasses. Journal of Non-crystalline Solids, 358(6-7), pp.993-1002.
[23] Seshasayee, M. and Muruganandam, K., 1998. Molecular dynamics study of V2O5 glass. Solid State Communications, 105(4), pp.243-246.

[24] Kubuki, S., Matsuda, K., Akiyama, K., Homonnay, Z., Sinkó, K., Kuzmann, E. and Nishida, T., 2013. Enhancement of electrical conductivity and chemical durability of $20 \mathrm{R} 2 \mathrm{O} \cdot 10 \mathrm{Fe} 2 \mathrm{O} 3 \cdot \mathrm{xWO} 3 \cdot(70-\mathrm{x}) \mathrm{V} 2 \mathrm{O} 5$ glass $(\mathrm{R}=\mathrm{Na}, \mathrm{K})$ caused by structural relaxation. Journal of Non-crystalline Solids, 378, pp.227-233.

[25] Ghosh, A. and Chakravorty, D., 1993. Electrical conduction in some sol-gel silicate glasses. Physical Review B, 48(8), p.5167.

[26] Ghosh, A., 1990. Ac conduction in iron bismuthate glassy semiconductors. Physical Review B, 42(2), p.1388.

[27] Dutta, D. and Ghosh, A., 2005. Dynamics of Ag+ ions in binary tellurite glasses. Physical Review B, 72(2), p.024201.

[28] Striepe, S., Da, N., Deubener, J. and Wondraczek, L., 2012. Micromechanical properties of (Na, Zn)sulfophosphate glasses. Journal of Non-crystalline Solids, 358(6-7), pp.1032-1037.

[29] Striepe, S., Smedskjaer, M.M., Deubener, J., Bauer, U., Behrens, H., Potuzak, M., Youngman, R.E., Mauro, J.C. and Yue, Y., 2013. Elastic and micromechanical properties of isostatically compressed soda-lime-borate glasses. Journal of Non-crystalline Solids, 364, pp.44-52.

[30] Krishna Mohan, N., Sahaya Baskaran, G. and Veeraiah, N., 2006. Dielectric and spectroscopic properties of $\mathrm{PbO}$ Nb2O5-P2O5: V2O5 glass system. Physica Status Solidi (a), 203(8), pp.2083-2102.

[31] Subbalakshmi, P., Sastry, P.S. and Veeraiah, N., 2001. Dielectric relaxation and ac conduction phenomena in $\mathrm{PbO}-\mathrm{WO} 3-\mathrm{P} 2 \mathrm{O} 5$ glass system. Physics and Chemistry of Glasses, 42(4-5), pp.307-314.

[32] Iordanova, R., Dimitrov, V., Dimitriev, Y. and Klissurski, D., 1994. Glass formation and structure of glasses in the V2O5- MoO3- Bi2O3 system. Journal of Non-crystalline Solids, 180(1), pp.58-65.

[33] Iordanova, R., Dimitriev, Y., Dimitrov, V., Kassabov, S. and Klissurski, D., 1996. Glass formation and structure in the V2O5- Bi2O3- Fe2O3 glasses. Journal of Noncrystalline Solids, 204(2), pp.141-150.

[34] Merzbacher, C.I. and White, W.B., 1991. The structure of alkaline earth aluminosilicate glasses as determined by vibrational spectroscopy. Journal of Non-Crystalline Solids, 130(1), pp.18-34.

[35] Wan, J., Cheng, J. and Lu, P., 2008. The coordination state of B and Al of borosilicate glass by IR spectra. Journal of Wuhan University of Technology-Mater. Sci. Ed., 23(3), pp.419-421.

[36] Kohli, J.T., Condrate, R.A. and Shelby, J.R., 1993. Raman and infrared spectra of rare earth aluminosilicate glasses. Physics and Chemistry of Glasses, 34(3), pp.81-87.

[37] Hayri, E.A., Greenblatt, M., Bruna, P. and Gerhardt, R., 1989. Na2O- P2O5- SiO2 gels: Preparation and characterization. Journal of Non-crystalline Solids, 111(2-3), pp.167-172.

[38] Khalifa, F.A., El Hadi, Z.A., El-Keshen, A.A. and Moustaffa, F.A., 1996. Synthesis and infrared spectra of high lead silicate glasses with di-, tri-or tetravalent cations: A structure correlation. Indian Journal of Pure \& Applied Physics, 34(4), pp.201-210. 
[39] Rada, S., Neumann, M. and Culea, E., 2010. Experimental and theoretical investigations on the structure of the leadvanadate-tellurate unconventional glasses. Solid State Ionics, 181(25-26), pp.1164-1169.

[40] Rada, S., Ristoiu, T., Rada, M., Dan, V., Coroiu, I., Barlea, M., Rusu, T. and Culea, E., 2010. Towards understanding of the photosensitive properties in leadvanadate-tellurate unconventional glasses. Materials Research Bulletin, 45(11), pp.1598-1602.

[41] Rada, M., Rus, L., Rada, S., Pascuta, P., Stan, S., Dura, N., Rusu, T. and Culea, E., 2015. Role of vanadium ions on structural, optical and electrochemical properties of the vanadate-lead glasses. Journal of Non-Crystalline Solids, 414, pp.59-65.

[42] Gandhi, Y., Venkatramaiah, N., Kumar, V.R. and Veeraiah, N., 2009. Spectroscopic and dielectric properties of $\mathrm{ZnF} 2-\mathrm{As} 2 \mathrm{O} 3-\mathrm{TeO} 2$ glass system doped with V2O5. Physica B: Condensed Matter, 404(8-11), pp.1450-1464.

[43] El-Bata, H.A., Ghoheim, K.A., Abd El-shafi, N. and Azooz, M.A., 2000. Infrared spectra and crystallization of some Li2O-SiO2 glasses and the effect of $\mathrm{CaO}, \mathrm{Al} 2 \mathrm{O} 3$ and $\mathrm{K} 2 \mathrm{O}$ additives. Indian Journal of Pure \& Applied Physics, 38(2), pp.101-109.

[44] Dimitrov, V., Dimitriev, Y. and Montenero, A., 1994. IR spectra and structure of V2O5-GeO2-Bi2O3 glasses. Journal of Non-Crystalline Solids, 180(1), pp.51-57.

[45] Srikumar, T., Rao, C.S., Gandhi, Y., Venkatramaiah, N., Ravikumar, V. and Veeraiah, N., 2011. Microstructural, dielectric and spectroscopic properties of Li2O-Nb2O5$\mathrm{ZrO} 2-\mathrm{SiO} 2$ glass system crystallized with V2O5. Journal of Physics and Chemistry of Solids, 72(3), pp.190-200.

[46] Rao, P.T. and Vasundhara, B., 2015. Thermal and FT-IR Properties of Semiconducting SnO 2-PbO-V 2 O 5 Glass System. New Journal of Glass and Ceramics, 5(03), p.53.

[47] Wang, D.S. and Pantano, C.G., 1992. Structural characterization of $\mathrm{CaO}-\mathrm{B} 2 \mathrm{O} 3-\mathrm{Al} 2 \mathrm{O} 3-\mathrm{SiO} 2$ xerogels and glasses. Journal of Non-crystalline Solids, 142, pp.225233.

[48] King, P.L., Ramsey, M.S., McMillan, P.F., and Swayze, G.A.. 2004. Infrared Spectroscopy in Geochemistry, Exploration Geochemistry and Remote Sensing. Mineral. Assoc. Canada Short Course Series, 33, pp.57-91.
[49] Wong, J., 1976. Vibrational spectra of vapor-deposited binary phosphosilicate glasses. Journal of NonCrystalline Solids, 20(1), pp.83-100.

[50] King, P.L., Ramsey, M.S., McMillan, P.F., and Swayze, G.A.. 2004. Infrared Spectroscopy in Geochemistry, Exploration Geochemistry and Remote Sensing. Mineral. Assoc. Canada Short Course Series, 33, pp.93-133.

[51] Ahsan, M.R. and Mortuza, M.G., 2005. Infrared spectra of $\mathrm{xCaO}(1-\mathrm{x}-\mathrm{z}) \mathrm{SiO} 2 \mathrm{zP} 2 \mathrm{O} 5$ glasses. Journal of NonCrystalline Solids, 351(27-29), pp.2333-2340.

[52] Chen, A. and James, P.F., 1988. Amorphous phase separation and crystallization in a lithium silicate glass prepared by the sol-gel method. Journal of Noncrystalline Solids, 100(1-3), pp.353-358.

[53] Rao, N.S., Purnima, M., Bale, S., Kumar, K.S. and Rahman, S., 2006. Spectroscopic investigations of $\mathrm{Cu} 2+$ in Li2O-Na2O-B2O3-Bi2O3 glasses. Bulletin of Materials Science, 29(4), pp.365-370.

[54] Mandal, S. and Hazra, S., 2000. Structural and physical properties of Fe2O3-doped lead vanadate glass. Journal of Materials Research, 15(1), pp.218-221.

[55] Higazy, A.A. and Bridge, B., 1985. Infrared spectra of the vitreous system Co 3 O 4-P 2 O 5 and their interpretation. Journal of Materials Science, 20(7), pp.2345-2358.

[56] Innocenzi, P., 2003. Infrared spectroscopy of sol-gel derived silica-based films: a spectra-microstructure overview. Journal of Non-crystalline Solids, 316(2-3), pp.309-319.

[57] Lofaj, F., Satet, R., Hoffmann, M.J. and de Arellano Lopez, A.R., 2004. Thermal expansion and glass transition temperature of the rare-earth doped oxynitride glasses. Journal of the European Ceramic Society, 24(12), pp.3377-3385.

[58] Hanifi, A.R., Genson, A., Pomeroy, M.J. and Hampshire, S., 2012. Independent but additive effects of fluorine and nitrogen substitution on properties of a calcium aluminosilicate glass. Journal of the American Ceramic Society, 95(2), pp.600-606.

[59] Iftekhar, S., Pahari, B., Okhotnikov, K., Jaworski, A., Stevensson, B., Grins, J. and Edén, M., 2012. Properties and structures of RE2O3-Al2O3-SiO2 $(\mathrm{RE}=\mathrm{Y}, \mathrm{Lu})$ glasses probed by molecular dynamics simulations and solid-state NMR: the roles of aluminum and rare-earth ions for dictating the microhardness. The Journal of Physical Chemistry C, 116(34), pp.18394-18406. 


\section{Appendix A}
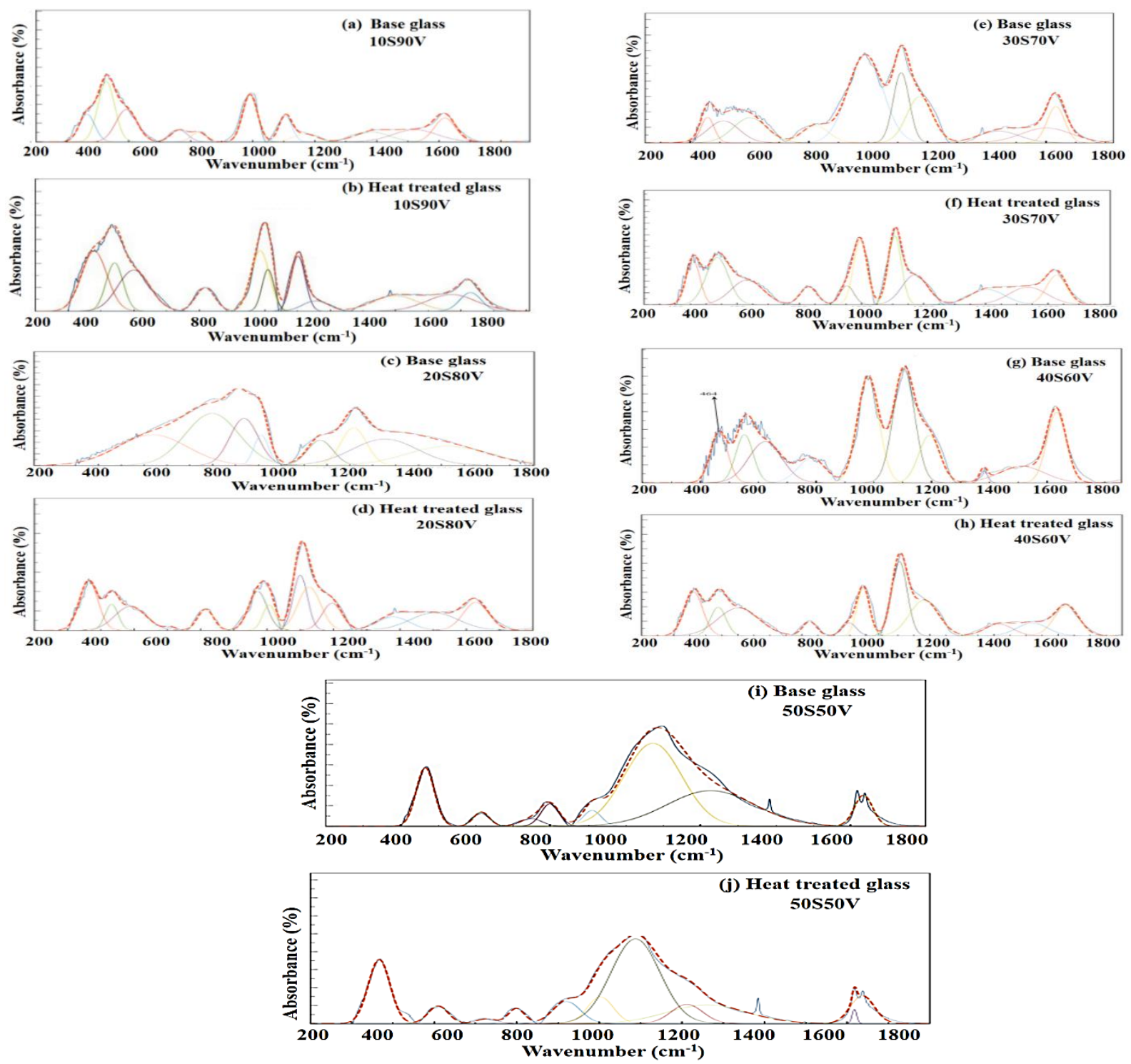

Fig. A1 (a), (b), (c), (d), (e), (f), (g), (h), (i) and (j) show the deconvoluted spectra of $\mathrm{xSiO}_{2}(100-\mathrm{x}) \mathrm{V}_{2} \mathrm{O}_{5}$ system base and heat treated glasses with $\mathrm{x}=10,20,30,40$ and $50 \mathrm{~mol} \%$ respectively.

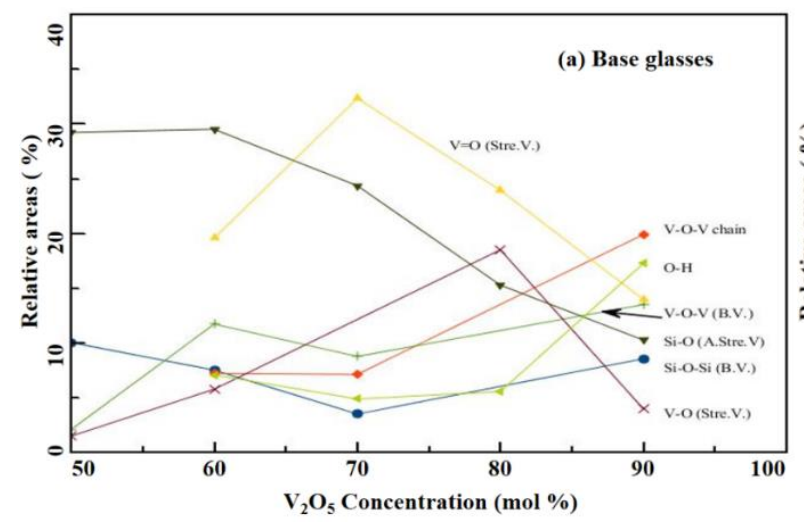

(a)

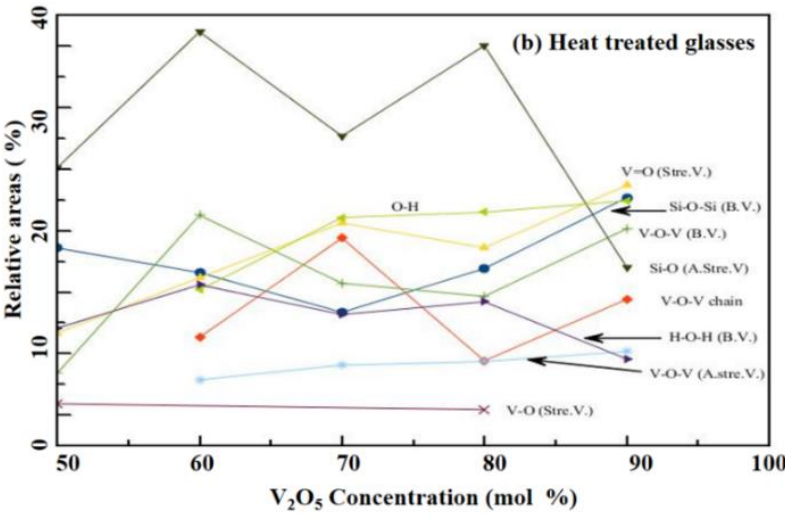

(b)

Fig. A2 (a) and (b) Relative areas of the chemical bonds as a function of $\mathrm{V}_{2} \mathrm{O}_{5}$ Concentration in mol\% of $\mathrm{xSiO}_{2}(100-\mathrm{x}) \mathrm{V}_{2} \mathrm{O}_{5}$ base and heat treated glasses respectively. 